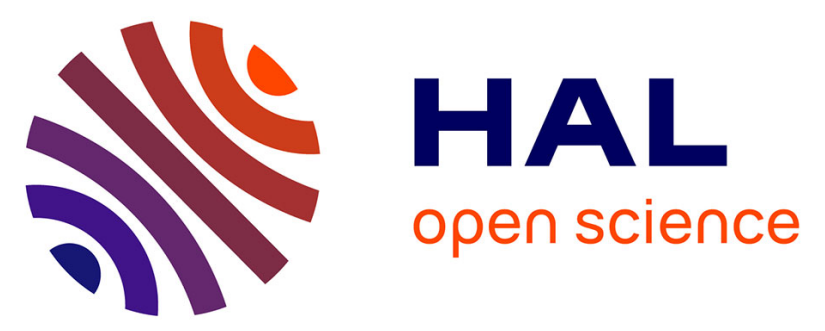

\title{
Coadministration of nanosystems of short silencing RNAs targeting oestrogen receptor $\alpha$ and anti-oestrogen synergistically induces tumour growth inhibition in human breast cancer xenografts
}

Céline Bouclier, Véronique Marsaud, Olivia Bawa, Valérie Nicolas, Laurence Moine, Paule Opolon, Jack-Michel Renoir

\section{To cite this version:}

Céline Bouclier, Véronique Marsaud, Olivia Bawa, Valérie Nicolas, Laurence Moine, et al.. Coadministration of nanosystems of short silencing RNAs targeting oestrogen receptor $\alpha$ and anti-oestrogen synergistically induces tumour growth inhibition in human breast cancer xenografts. Breast Cancer Research and Treatment, 2009, 122 (1), pp.145-158. 10.1007/s10549-009-0558-z . hal-00535399

\author{
HAL Id: hal-00535399 \\ https://hal.science/hal-00535399
}

Submitted on 11 Nov 2010

HAL is a multi-disciplinary open access archive for the deposit and dissemination of scientific research documents, whether they are published or not. The documents may come from teaching and research institutions in France or abroad, or from public or private research centers.
L'archive ouverte pluridisciplinaire HAL, est destinée au dépôt et à la diffusion de documents scientifiques de niveau recherche, publiés ou non, émanant des établissements d'enseignement et de recherche français ou étrangers, des laboratoires publics ou privés. 


\title{
Coadministration of nanosystems of short silencing RNAs targeting oestrogen receptor $\alpha$ and anti-oestrogen synergistically induces tumour growth inhibition in human breast cancer xenografts
}

\author{
Céline Bouclier · Véronique Marsaud - Olivia Bawa \\ Valérie Nicolas · Laurence Moine · Paule Opolon · \\ Jack-Michel Renoir
}

Received: 27 August 2009/Accepted: 11 September 2009/Published online: 22 September 2009

(C) Springer Science+Business Media, LLC. 2009

\begin{abstract}
The suppression of oestrogen receptor $\alpha(E R \alpha)$ functions by silencing RNAs in association with or not with anti-oestrogens (AEs) both in vitro and in breast cancer cell xenografts was assessed. In vitro, a prolonged decrease in $\mathrm{ER} \alpha$ protein expression and an enhanced AE-induced inhibition of $\mathrm{ER} \alpha$-mediated transcription, together with antiproliferative activity, were observed. Incorporation of ER $\alpha$-siRNAs in pegylated nanocapsules (NC) was achieved; and their intravenous injections in MCF-7 xenografts, in contrast to scramble siRNA containing NCs, lead to decrease in $\mathrm{ER} \alpha$ protein content and Ki67 labelling in tumour cells. The pure AE RU58668 (RU) both free and entrapped in stealth nanospheres (NS) at very low concentration $(8 \mu \mathrm{g} / \mathrm{kg} /$ week) had no effect on tumour growth evolution. However, coinjection of the two nanocarriers potentiated the decrease in $\mathrm{ER} \alpha$ protein, concomitantly with decreasing tumour vasculature and glucose transporter-1. These data support that the targeted delivery of ER $\alpha$-siRNA in breast tumours potentiates the inhibition of $\mathrm{E}_{2}$-induced proliferative activity by encapsulated $\mathrm{AE}$ through enhanced
\end{abstract}

C. Bouclier · V. Marsaud · L. Moine · J.-M. Renoir ( $₫)$

CNRS, UMR 8612, Physico-Chimie, Pharmacotechnie,

Biopharmacie, Faculté de Pharmacie, 5 rue J.B. Clément, 92296

Châtenay-Malabry, France

e-mail: michel.renoir@u-psud.fr

C. Bouclier · V. Marsaud · L. Moine · J.-M. Renoir

University Paris-Sud, 91405 Orsay, France

C. Bouclier · V. Marsaud · V. Nicolas · L. Moine · J.-M. Renoir

IFR 141, 92296 Châtenay-Malabry, France

O. Bawa $\cdot$ P. Opolon

UMR CNRS 8121, Institut Gustave Roussy, Villejuif, France anti-vascular activity. In the hormone-independent MDAMB-231 xenograft model, RU-NS at $4 \mathrm{mg} / \mathrm{kg} /$ week induce also a strong tumour vascular normalisation. Together, these findings suggest that the anti-oestrogen activity of RU as well as that of targeted ER $\alpha$-siRNA leads to anti-angiogenic activity. Their delivery in stealth nanocarriers may constitute a new anti-cancer therapeutic strategy in solid tumours.

Keywords Oestrogen receptor - siRNA - Breast cancer . Anti-oestrogen · Angiogenesis

\section{Introduction}

Oestrogens play key roles in the development and maintenance of sexual behaviour and reproductive functions. In addition, they exert a number of biological effects in tissues: some of them are beneficial, such as those affecting the cardiovascular, musculoskeletal, immune and central nervous systems. However, in both the mammary gland and the uterus, oestrogens may have detrimental effects including the promotion of cancers $[1,2]$. The most active natural oestrogen produced in the human body is $17 \beta$ oestradiol $\left(\mathrm{E}_{2}\right) . \mathrm{E}_{2}$ binds two nuclear estradiol receptors $(\mathrm{ER} \alpha$ and $\mathrm{ER} \beta)$, both members of the steroid/thyroid superfamily of transcription factors [3]. In normal breast, $\operatorname{ER} \alpha$ and $\operatorname{ER} \beta$ are present in small but similar levels. In breast tumours, ER $\alpha$ tends to be more strongly expressed than $\mathrm{ER} \beta$, and $\mathrm{E}_{2}$ increases the transcription of genes involved in cell cycle progression (such as those encoding c-myc, cyclins D, A and E) and decreases that of other genes, such as that encoding the cyclin-dependent kinase (cdk) inhibitor $\mathrm{p} 21^{\mathrm{Waf} 1 / \mathrm{Cip} 1}$. ER-positive breast cancers are usually treated with aromatase inhibitors or anti-oestrogens (AEs), to reduce hormone activity $[4,5]$. 
The selective oestrogen receptor modulator (SERM) Tamoxifen $\left(\right.$ Nolvadex $\left.^{\circledR}\right)$ has been widely used in the clinical treatment of ER-positive breast cancer for almost 30 years [6]. Other AEs, such as the selective oestrogen receptor down-regulators (SERDs), are strong oestrogen antagonists, independent of tissue type; this is the case for the so-called pure antagonists ICI 182,780 (ICI, or Faslodex ${ }^{\circledR}$ or Fulvestrant) [7] and RU58668 (RU) [8]. The main difference between SERMs and SERDs is that SERMs form complexes with ERs and corepressors, allowing DNA binding, whereas SERDs promote the ubiquitinylation and the rapid proteasome-mediated degradation of $\mathrm{ER} \alpha$ [9-12]. In both cases, ER-AE complexes inhibit the transcription of a number of genes in breast cancers; however, ER-SERM complexes stabilise both ER isoforms whereas SERD complexes result in the degradation of $\operatorname{ER} \alpha$, but the stabilisation of $\operatorname{ER} \beta$ [13, 14].

Since ER $\alpha$ gene amplification is frequent in breast cancers [15] and responsible for the mitogenic effects of $\mathrm{E}_{2}$, the site-specific destruction of this nuclear receptor may represent another way to stop $E_{2}$-induced breast cancer tumour progression. Such a strategy, based on the delivery of AEs through intra venous injection of AEloaded nanocarriers, was previously developed in our laboratory. Once encapsulated in stealth nanoparticles, AE displayed a high anti-tumour potential [16]. However, although RU-loaded nanoparticles strongly inhibit tumour growth and increase apoptosis in tumour cells [17], endogenous $E_{2}$ and exogenous oestrogens can still restore $\mathrm{ER} \alpha$ expression [12]. We then developed a new formulation based on the incorporation of specific ER $\alpha$-targeting siRNAs to improve the down regulation of ER $\alpha$ [18]. Two specific ER $\alpha$-siRNAs were mixed and incorporated into aqueous-core nanocapsules (NC) coupled to poly(ethylene)glycol (PEG). Such pegylated nanocarriers are well known to remain in the circulation for a prolonged period of time when they are injected intravenously [19-21]. Preliminary biological characterisation in vivo demonstrated that they reduce tumour growth in a MCF-7 cell xenograft model [18]. Here, we extended studies to determine the biological effects of ER $\alpha$-mix-siRNA-NCs. We correlated the anti-tumour potential of siRNA targeting $\mathrm{ER} \alpha$ with the suppression of oestradiol-induced vascularisation, an effect strongly enhanced by low concentrations of RU encapsulated in nanospheres. More importantly, the anti-vascular effects of entrapped RU were also observed in ER-negative breast cancer MDAMB-231 xenograft, well known to be non-responsive to AE. These results thus support the use of a combination of agents suppressing ER $\alpha$ and other anti-tumour agents delivered via long-circulating nanocarriers to target breast tumour cells.

\section{Materials and methods}

Reagents

Two siRNAs targeting ER $\alpha$ were designed to recognise sequences in the non-coding region of $E R \alpha$-encoding mRNA. ER $\alpha 1$-siRNAs (sense strand 5'-GACUUGAAUUA AUAAGUGA- $3^{\prime}$, anti-sense strand $5^{\prime}$-UCACUUAUUAAU UCAAGUC- $3^{\prime}$ ), ER $\alpha 2$-siRNAs (sense strand $5^{\prime}$-CCUUUG ACCUAUAGGCUAA- $3^{\prime}$, anti-sense strand $5^{\prime}$-UUAGCCU AUAGGUCAAAGG- $3^{\prime}$ ) and scramble siRNAs (Scr-siRNA) were purchased from Qiagen (Courtaboeuf, France) and carboxyfluorescein-labelled siRNAs (5'-FAM-siRNA) were obtained from Eurogentec (Seraing, Belgium). SiRNAs were purified by high-performance liquid chromatography and analysed by spectrometry. RU was a gift from P. Van de Velde (HMR, Romainville, France). 4-Hydroxytamoxifen (OHT) was provided by Besins Iscovesco (Paris, France). PEG-PLGA, type RGP d 50105, Resomer (PLGA, $\mathrm{MW}=45 \mathrm{kDa}$, consisting of $50 \%$ lactic acid units and $50 \%$ glycolic acid units; PEG, $\mathrm{MW}=5 \mathrm{kDa}$ ) was obtained from Boehringer (Ingelheim, Germany). All other laboratory chemicals were reagent grade, purchased from standard suppliers.

\section{Cell culture}

Human breast cancer MCF-7 and MDA-MB-231 cells were obtained from ATCC (Molsheim, France). MELN cells are MCF-7 cells stably transfected with a construct in which the luciferase reporter gene is under the control of an oestrogen responsive element (ERE) linked to the minimal $\beta$-globulin promoter (ERE- $\beta$-globulin-LUC) [22]. All cells were grown in Dulbecco's modified Eagle medium (DMEM/F12, Lonza, Vervier, Belgium) supplemented with $10 \%$ foetal calf serum (FCS), L-glutamine ( $2 \mathrm{mM})$, penicillin $(50 \mathrm{IU} / \mathrm{mL})$ and streptomycin $(50 \mathrm{IU} / \mathrm{mL})$ at $37^{\circ} \mathrm{C}$ in $5 \% \mathrm{CO}_{2}$ in a $95 \%$ humidified atmosphere. Prior to treatment, the medium was replaced with phenol red-free DMEM supplemented with $10 \%$ stripped FCS (charcoal Norit A 1\%, Dextran T70 0.1\%, 30 min at room temperature) for at least $48 \mathrm{~h}$.

Transfection experiments and transactivation assay

Cells were seeded on $3-\mathrm{cm}$ diameter plates $18 \mathrm{~h}$ before transfection in phenol red-free DMEM/F12 supplemented with $10 \%$ dextran-coated charcoal-stripped FCS. ER $\alpha 1$ siRNA, ER $\alpha 2$-siRNA, ER $\alpha$-mix-siRNA and scramble siRNA (10 nM) were transfected using the Highperfect reagent (Qiagen) according to the manufacturer's instructions. Cells were stimulated $32 \mathrm{~h}$ later with $\mathrm{E}_{2}$, RU or OHT for $16 \mathrm{~h}$, then harvested and lysed in $250 \mu \mathrm{L}$ of luciferase 
buffer (25 mM Tris, $\mathrm{H}_{3} \mathrm{PO}_{4} \mathrm{pH} 7.8,10 \mathrm{mM} \mathrm{MgCl} 2,10 \%$ Triton X-100, 15\% glycerol, $1 \mathrm{mM}$ EDTA, $1 \mathrm{mM}$ DTT) for $30 \mathrm{~min}$ at $4^{\circ} \mathrm{C}$. Luciferase buffer $(50 \mu \mathrm{L})$, supplemented with $100 \mathrm{mM}$ ATP and $87 \mu \mathrm{g}$ luciferine/mL, was added to $50 \mu \mathrm{L}$ of cell extract; and luciferase activity was quantified in a luminometer (Lumat LB 9507, Berthold, Bad Wildbad, DE). The protein concentration of each sample was determined by Biorad assay, and luciferase activity was normalised with respect to protein concentration.

\section{Cell proliferation assay}

Twenty-four hours after siRNA transfection, MCF-7 cells were seeded in 96-well plates at 5,000 cells/well in $100 \mu \mathrm{L}$ medium. Twelve hours later, $\mathrm{E}_{2}$, AE or vehicle were added. Cell proliferation was analysed using the colorimetric Cell Titer 96 Aqueous One Solution Cell Proliferation Assay (Roche) with 3-(4,5-dimethylthiazol-2-yl)-(3-carboxymethoxyphenyl)-2-(4-sulphophenyl)-2H-tetrazolium, inner salt (MTS), after different periods of treatment. MTS $(20 \mu \mathrm{l} ; 1.9 \mathrm{mg} / \mathrm{mL})$ was added to each well. Cells were then incubated for $2 \mathrm{~h}$ at $37^{\circ} \mathrm{C}$. Optical density (OD) at $490 \mathrm{~nm}$, correlating to the number of viable cells, was determined using the microplate reader Metertech $\Sigma 960$ (Fisher Bioblock, Illkirch, France).

\section{Western blotting}

Pelleted cells were resuspended in lysis buffer $(50 \mathrm{mM}$ Hepes pH 7.5, $150 \mathrm{mM} \mathrm{NaCl}, 1.5 \mathrm{mM} \mathrm{MgCl}_{2}, 1 \mathrm{mM}$ EGTA, 10\% glycerol, 1\% Triton X-100) with protease inhibitors (Complete Reagent, Roche Diagnostics, Indianapolis, IN, USA) for $20 \mathrm{~min}$ and then boiled for $10 \mathrm{~min}$ in Laemmli sample buffer. Protein content from cell extracts was analysed in $8 \%$ polyacrylamide gels (except where otherwise stated). Proteins were separated by electrophoresis and electrotransferred onto a polyvinylidene difluoride membrane (Immobilon P, Millipore Corp, SaintQuentin en Yvelines, France). The membrane was blocked for $1 \mathrm{~h}$ at $37^{\circ} \mathrm{C}$ in $10 \%$ dried non-fat milk in PBS containing 1\% Tween 20 (PBST) or in 5\% FCS in PBST. The membrane was then incubated overnight at $4{ }^{\circ} \mathrm{C}$ with anti$\mathrm{ER} \alpha$ (HC-20, at $0.1 \mu \mathrm{g} / \mathrm{mL})$ or anti-hsp70 (W-27, at $0.1 \mu \mathrm{g} / \mathrm{mL}$ ), all purchased from Santa-Cruz Biotechnology (Santa-Cruz, CA, USA). Appropriate horseradish peroxidase-conjugated secondary antibodies and Luminol reagent (Santa-Cruz) were used for detection.

\section{RNA extraction and RT-PCR}

Total RNA was extracted from $1 \times 10^{6}$ cells with Trizol (Invitrogen, Carlsbad, CA) reagent according to the manufacturer's instructions. Total RNA $(2 \mu \mathrm{L})$ was reverse transcribed in cDNA using random primer and M-MuLV reverse transcriptase (Invitrogen). PCR reactions contained the following primers for target genes: PR forward, ACAG GACCCCTCCGACGAAAA; PR reverse, AGCTGTCTCC AACCTTGCACC; $\beta$-actin forward, TGACGGGGTCAC CCACACTGTGCCCATCTA; $\beta$-actin reverse, CTAGAA GCATTTGCGGTGGACGATGGAGGG. Amplification was carried out with $2 \mu \mathrm{L}$ cDNA, for 35 cycles $\left(95^{\circ} \mathrm{C}, 1 \mathrm{~min}\right.$; $60^{\circ} \mathrm{C}, 1 \mathrm{~min} ; 72^{\circ} \mathrm{C}, 1 \mathrm{~min}$ ); PCR products were analysed on $2 \%$ agarose gels.

Synthesis of aqueous-core nanocapsules

Aqueous-core nanocapsules (NC) of PEG-co-poly( $\varepsilon$-caprolactone-co-dodecyl- $\beta$-malate) (PEG-PCL/MA) were prepared by double emulsion water-in-oil-in-water solvent evaporation technique following the protocol described previously [18]. The final concentration of incorporated siRNA was $3.3 \mu \mathrm{M}$ in a $16 \mathrm{mg} / \mathrm{mL}$ polymer solution (corresponding to $0.5 \mu \mathrm{g}$ siRNA/mL).

\section{RU58668 nanospheres}

Nanospheres (NS) of RU were prepared by interfacial deposition of preformed polymers of poly lactic-co-glycolic acid coupled to poly(ethylene)glycol (PEG-PLGA) after solvent evaporation, as previously described [17, 23]. Depending on the initial amount of RU added in the initial polymer mixture, various drug-loading rates were obtained. In the present work, we used two NS preparations containing either 2 or $500 \mu \mathrm{M}$ RU. These PEG-PLGA-RU nanospheres had a small size $(\sim 120 \mathrm{~nm})$ compatible with crossing through tumour capillaries after i.v. injection.

Xenografts and in vivo experiments

The MCF-7 cell suspension $\left(5-10 \times 10^{7}\right.$ cells/mL) was mixed with an equal volume of Matrigel (BD Bioscience, Le Pont de Claix, France) and injected (200 $\mu \mathrm{L}$ total) subcutaneously into the flanks of 6-week-old female nude mice (Janvier, Le Genest Saint Isle, France) in the vicinity of mammary glands. Mice were housed in a pathogen-free isolation facility with a 12-h-light-/12-h-dark-cycle and fed with rodent chow and water ad libitum. Mice were treated weekly with $20 \mu \mathrm{L}$ of a $10^{-2} \mathrm{M}$ ethanolic solution of $\mathrm{E}_{2}$ applied to the neck skin. Tumours developed over a period of 5-7 weeks, reaching sizes of $300-500 \mathrm{~mm}^{3}$ [calculated as $1 / 2\left(\right.$ width $\times$ length $\left.\left.^{2}\right)\right]$. They were then transplanted (biopsies of 1-2 $\mathrm{mm}^{3}$ ) under the skin of recipient female 5 -week-old mice, in the vicinity of the nipple. Tumours were allowed to grow under biweekly $E_{2}$ stimulation (20 $\mu \mathrm{L}$ of a $10 \mathrm{mM}$ ethanolic solution deposit on the neck skin) until they reached $5-8 \mathrm{~mm}$ in diameter (8 weeks). 
Mice were then treated with nanoparticle formulations administered twice a week by intravenous injection into the retro-orbital sinus over 5 weeks. For siRNA-loaded PEGPCL/MA NCs, mice received $330 \mu \mathrm{g}$ siRNA/kg/week; for RU-containing PEG-PLGA NS, mice received $8.5 \mu \mathrm{g}$ RU/ $\mathrm{kg} /$ week (10 mice in each group).

MDA-MB-231 tumours were generated similarly to MCF-7 tumours by injected subcutaneously $200 \mu \mathrm{L}$ of a suspension of cells $\left(1-2 \times 10^{7}, \mathrm{vol} / \mathrm{vol}\right)$ in Matrigel. Tumours developed faster than MCF-7 tumours in 45 weeks and were treated by injected PEG-PLGA NS loaded or not with RU at the highest concentration $(4.3 \mathrm{mg} /$ $\mathrm{kg} /$ week).

Tumour volume was measured weekly, and tumour progression was determined by the ratio of the volume at each time point to the initial tumour volume (week 0 ). The animals were killed by $\mathrm{CO}_{2}$ exposure at the end of the experiment; tumours were removed and fixed in Finefix (Milestone s.r.l., Sorisole, Italy). A number of tumour samples were fixed in paraformaldehyde prior to confocal fluorescence microscopy. All experiments were performed in accordance with the principles of the Helsinki Declaration and French animal welfare legislation.

\section{Confocal fluorescence microscopy}

Tumours were fixed for 4 days at $4^{\circ} \mathrm{C}$ in $4 \%$ paraformaldehyde ( $\mathrm{v} / \mathrm{v}$ in PBS) and then rinsed four times in PBS for $24 \mathrm{~h}$. Tumours were then embedded in Tissue-Tek OCT compound (Sakura Finetek, Zoeterwoude, The Netherlands) and frozen in liquid nitrogen. Frozen blocks were cut with a cryotome (CM 3050S cryostat, Leica, Nussloch, Germany) into 20- $\mu \mathrm{m}$ thick sections. Cryo-sections were mounted with Vectashield mounting medium (Vector Laboratories, Burlingame, CA, USA) to ensure fluorescence protection. Slices were viewed with a LSM 510 META Zeiss (Jena, Germany) confocal inverted microscope equipped with a plan-apochromat $63 \mathrm{X} / 1,4 \mathrm{NA}$ oil immersion objective lens. All images were acquired with an air-cooled argon laser (488 $\mathrm{nm}$ excitation wavelength). Fluorescence emission was collected with a Long Pass 505$\mathrm{nm}$ filter. The pinhole was set at 1.0 Airy unit $(0.8 \mu \mathrm{m}$ optical slice thickness).

Immunohistochemistry of tumour sections

Finefix-fixed, paraffin-embedded tumours were cut in $4-\mu \mathrm{m}$ thick sections. Paraffin was removed by incubation in xylene and sections were rehydrated and stained for immunohistochemical analysis. Heat-induced epitope retrieval was carried out with $\mathrm{pH} 8$ Tris-EDTA at $98^{\circ} \mathrm{C}$ for
$40 \mathrm{~min}$. Endogenous peroxidase activity was quenched with $3 \% \mathrm{H}_{2} \mathrm{O}_{2}$ for $10 \mathrm{~min}$; then, sections were placed in cover plates (Shandon, Detroit, MI) and incubated with blocking serum in Biogenex wash buffer (1:10; San Ramon, CA) for $10 \mathrm{~min}$. Sections were then incubated for $1 \mathrm{~h}$ with antibodies: anti-mouse CD34 (endothelial cell marker), 1:20 (HyCult biotechnology b.v., Uden, The Netherlands); antiKi67, 1:200 (Neomarkers, LabVision, Microm Microtech, Francheville, France); anti-Glut-1, 1:300 (Neomarkers,) or anti-ER $\alpha, 1: 50$ (HC-20, Santa-Cruz Biotechnology). Slides were then incubated with a rabbit antibody 1:400 (Southern Biotech., Birmingham, AL) directed against the corresponding first antibody and diluted in blocking serum, 1:10. Staining was revealed using a Rabbit PowerVision kit (ImmunoVision Technologies, Norwell, MA) (20 min) with diamine $3,3^{\prime}$ benzidine (tetrachloridrate) (DAB) (10 min). Slides were counterstained with Mayer's hematoxylin and mounted (Pertex, Göteborg, Sweden). All slides were immunostained in cover plates the same day, guaranteeing a perfectly standardised intensity of staining, both for the immunohistochemical signal and for the counterstaining.

Quantification of Ki67-stained nuclei and of CD34stained micro-vessels on histological slides were achieved using PIXCIT; a software package designed by the Groupe Régional d'Etudes sur le Cancer (Centre François Baclesse, Caen, France) [24]. This system combines a dedicated slide scanner and a computer-assisted image analysis. Only the viable part of the tumours was analysed, the necrotic area was excluded from the examinations.

Statistical analysis

Student's $t$-test was used to compare the effects of formulated and unformulated drugs. The difference was considered statistically significant for $P$ values $\leq 0.05$.

\section{Results}

Additive efficacy of ER $\alpha$-siRNA and anti-oestrogens

The specificity of the siRNAs used and the optimum concentration needed to obtain maximum $\mathrm{ER} \alpha$ blockade have been previously shown; indeed, the ER $\alpha 1 / \mathrm{ER} \alpha 2$-siRNA mixture affects $\mathrm{ER} \alpha$ levels without affecting $\mathrm{ER} \beta$ [18]. Here, we demonstrated that, at $10 \mathrm{nM}$, this siRNA-mix induces a prolonged degradation of ER $\alpha$ in MCF-7 cells (Fig. 1a). Forty-eight hours after transfection, ER $\alpha$ levels were reduced by at least $80 \%$ (Fig. 1, panel A). Seven days after transfection with ER $\alpha$-mix-siRNA, receptor expression was still inhibited by more than $50 \%$, whereas 
A

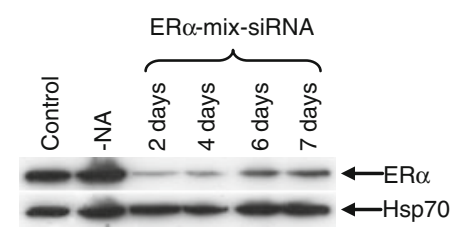

B

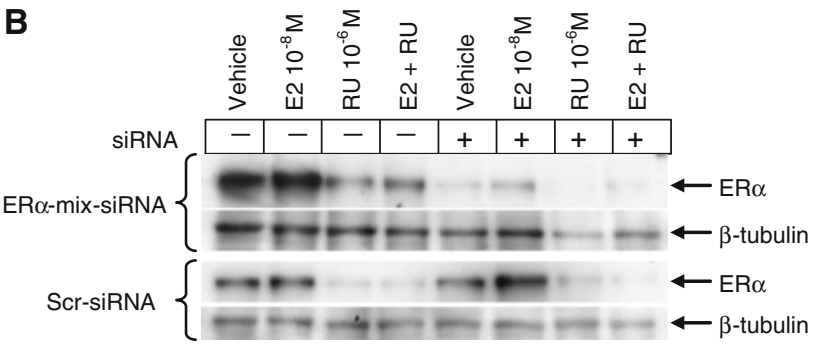

Fig. 1 Effect of ER $\alpha$-mix-siRNA on ER $\alpha$ levels a MCF-7 cells were transfected or not (control) with $10 \mathrm{nM}$ of scramble siRNA (ScrsiRNA) or ER $\alpha$-mix-siRNA. Cell extracts were prepared at various times following transfection. $\mathrm{ER} \alpha$ protein was detected by western blot as described in "Material and methods". Hsp70 was detected for control of constant protein loaded. b Thirty-two hours after transfection or not (control) with $10 \mathrm{nM}$ of Scr-siRNA or ER $\alpha$-mix-siRNA, MCF-7 cells were treated for $16 \mathrm{~h}$ with vehicle, RU or OHT $(1 \mu \mathrm{M})$ in the presence or absence of $10 \mathrm{nM} \mathrm{E}_{2}$. Cell extracts were prepared and receptor protein was analysed as described for panel $A$ and normalised to hsp70 (lower diagram). The blots shown are representative of three different experiments scramble siRNAs (Scr-siRNA) had no effect (Fig. 1, panel A). Previous findings have established that SERDs like Faslodex [11] and RU [12] induce a rapid and high level of proteasome-mediated ER $\alpha$ degradation, contrary to mixed AEs like OHT, which leads to ER $\alpha$ accumulation [25]. Such a SERD-induced degradation of ER $\alpha$ was enhanced by siRNAs targeting ER $\alpha$, and not by scramble siRNAs, in both the presence and absence of $E_{2}$ (Fig. 1, panel B).

In order to look at the effect of siRNAs on $\mathrm{E}_{2}$-induced transcription, MELN cells were transfected with each siRNA $(10 \mathrm{nM})$ and further incubated with or without oestradiol (panel A) or AEs (panel B). Both ER $\alpha$-siRNAs and ER $\alpha$-mix-siRNA reduced basal and oestradiol-induced luciferase activity by at least $80 \%$ (Fig. 2, panel A). ScrsiRNAs had no significant effect, although a tendency to slightly reduce $\mathrm{E}_{2}$-induced transcription was sometimes observed (panels A and B). The marked decrease in ER $\alpha$ levels was observed in Fig. 1, panel A was thus correlated with a decrease in $E R \alpha$ function. As previously shown, 0.1 $\mathrm{nM} \mathrm{E}_{2}$ was sufficient to obtain maximum luciferase activity in MELN cells [12]; both RU and OHT (10 nM) induced a marked decrease in basal and $\mathrm{E}_{2}$-induced luciferase activity (Fig. 2 panel B). Here, we showed that RU very efficiently reduced the transactivation capacity of $\mathrm{ER} \alpha$ and that a
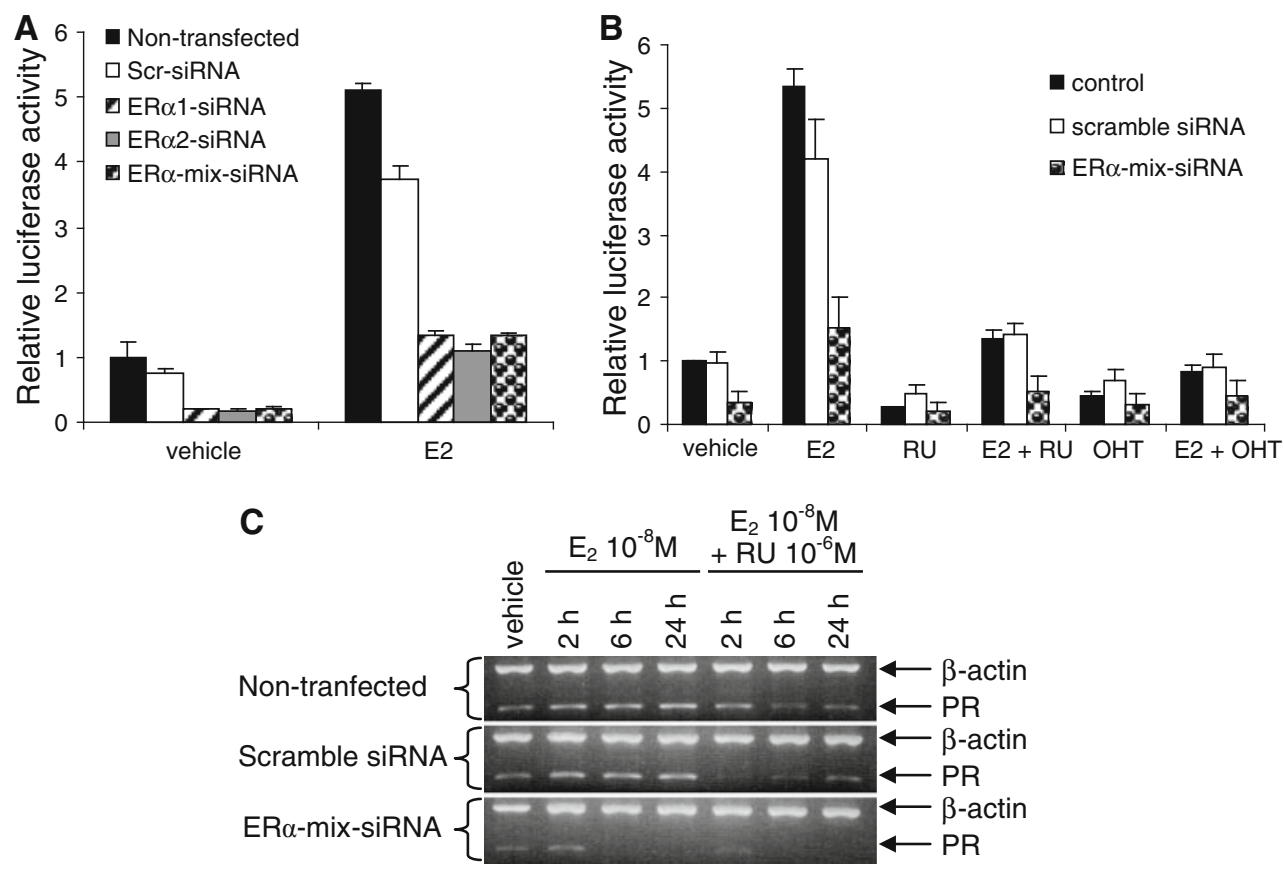

Fig. 2 ER $\alpha$-mix-siRNA efficiency upon ER $\alpha$-mediated transcription; MELN cells were transfected or not with $10 \mathrm{nM}$ of Scr-siRNA, the two different siRNAs targeting $\mathrm{ER} \alpha$ (a) or ER $\alpha$-mix-siRNA (b). Twenty-four hours later, cells were seeded in $3-\mathrm{cm}$ petri dishes and treated with ethanol vehicle, $0.1 \mathrm{nM} \mathrm{E}_{2}, 1 \mathrm{nM}$ RU and $10 \mathrm{nM}$ OHT for $16 \mathrm{~h}$. Luciferase activity was measured as described in "Material and methods", and results (mean of three independent experiments performed in triplicate \pm SEM) were expressed as relative activity, with controls assigned to $100 \%$ activity. c MCF-7 cells were transfected or not with $10 \mathrm{nM}$ of scramble siRNA or ER $\alpha$-mixsiRNA and treated similarly to MELN cells. Total RNA was extracted and PCR was performed as described in "Material and methods" in order to measure the effects of treatments on PR transcription 
concentration as low as $1 \mathrm{nM}$ of $\mathrm{RU}$ potentiated the decrease in luciferase activity induced by ER $\alpha$-mix-siRNAs (Fig. 2 panel B). These results are consistent with the ability of RU to potently enhance the siRNA-induced loss of ER $\alpha$ signal (Fig. 1b). Scr-siRNA showed a slight inhibitory effect, which mock transfection experiments revealed to be attributed to the transfection procedure itself (not shown).

We then studied the effect of ER $\alpha$-mix-siRNA on a well-characterised endogenous oestrogen-responsive gene, the progesterone receptor (PR) $[26,27] . \mathrm{E}_{2}$ increased $\mathrm{PR}$ mRNA levels in a time-dependent fashion, whereas, in the presence of RU, PR mRNA levels were decreased (Fig. 2c). As expected, transfection of ER $\alpha$-mix-siRNA whether combined or not with RU strongly blocked the $\mathrm{E}_{2}$-induced PR response.

Decreased proliferation in MCF-7 cells transfected with ER $\alpha$-mix-siRNA

Both scramble siRNA and the ER $\alpha$-specific siRNA mixture were transfected at concentrations of $10 \mathrm{nM}$. After $24 \mathrm{~h}$, cells were exposed to or not to $10 \mathrm{nM} \mathrm{E}_{2}$ alone (Fig. 3, panel A), or $\mathrm{E}_{2}$ plus either RU (panel B) or OHT (panel C). ER $\alpha$-mix-siRNA induced a $50 \%$ decrease in the cell proliferation rate both in presence and in absence of $E_{2}$, whereas Scr-siRNA had no effect (Fig. 3, panel A). This decrease was still apparent after 6 days of treatment,
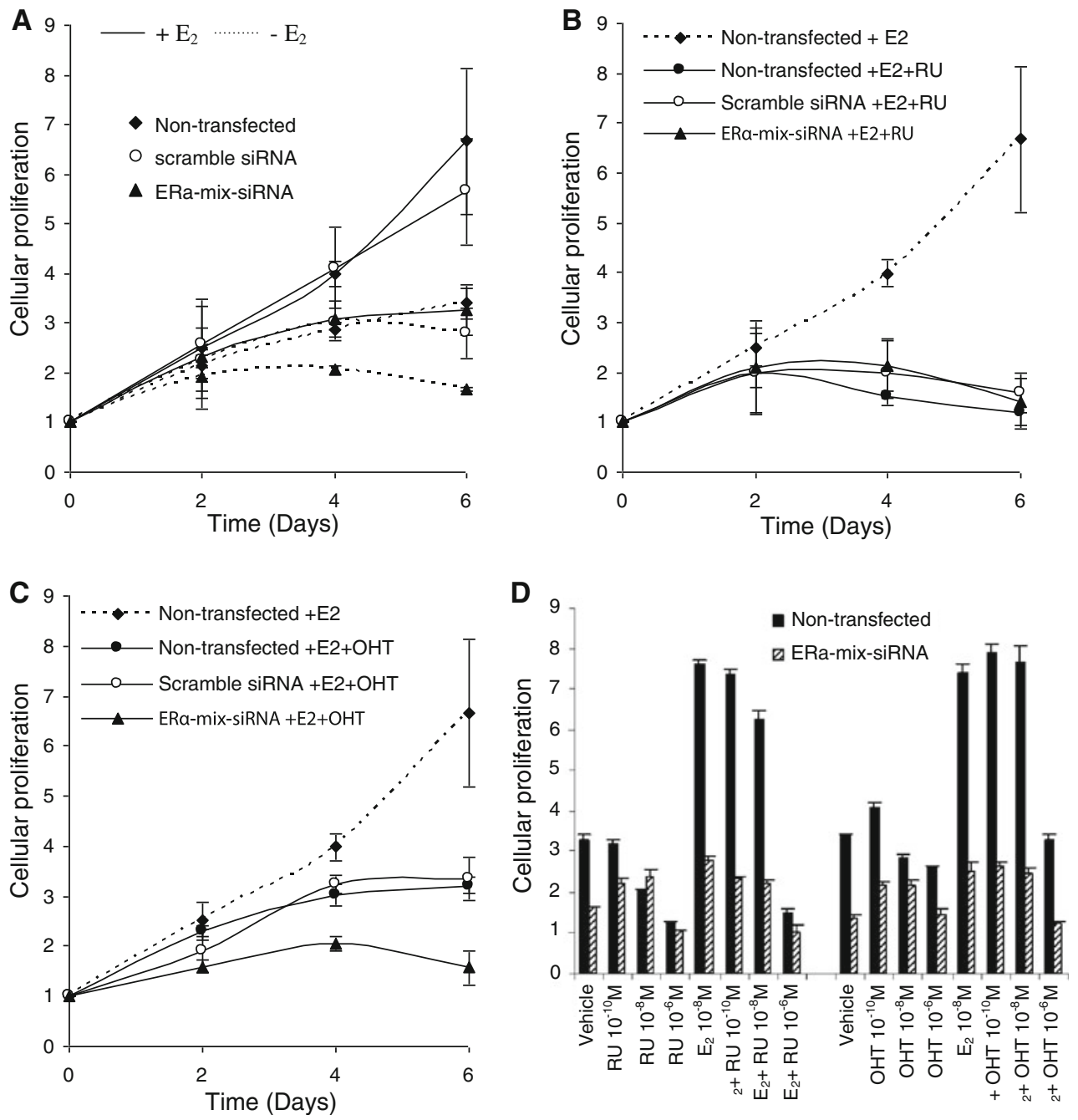

Fig. 3 Antiproliferative activity of ER $\alpha$-mix-siRNA in MCF-7 cells; MCF-7 cells were transfected or not filled diamond with $10 \mathrm{nM} \mathrm{ER} \alpha-$ mix-siRNA filled triangle or Scr-siRNA open circle. Twenty-four hours after transfection, cells were treated for 6 days with or without $10 \mathrm{nM} \mathrm{E}_{2}$ (panel $A$ ) alone or with either $1 \mu \mathrm{M} \mathrm{RU}$ (panel B) or $1 \mu \mathrm{M}$ OHT (panel $C$ ). Cells were counted at various time intervals, and

cellular proliferation (mean \pm SEM of three independent experiments) was expressed as the proliferation from time zero (index 1). In panel $D$, after transfection or not with $10 \mathrm{nM} \mathrm{ER} \alpha$-mix-siRNA, MCF7 cells were exposed to different concentrations of RU or OHT in the presence or absence of $E_{2}$. Cells were counted 6 days after stimulation, and cellular proliferation was expressed as described earlier 
correlating with the decrease in ER $\alpha$ levels (Fig. 1a). In the presence of $E_{2}, 1 \mu \mathrm{M}$ RU or OHT induced a time-dependent inhibition of cell proliferation; this effect was greater with RU than with OHT (Fig. 3, panels B and C, respectively). After transfection of cells with siRNAs followed by treatment with increasing concentrations of AEs, in the presence or absence of $E_{2}$ only RU but not OHT $(1 \mu \mathrm{M})$ was seen to potentiate the ER $\alpha$-mix-siRNA-induced inhibition of cell proliferation (Fig. 3, panels $\mathrm{C}$ and D).

Inhibition of $E R \alpha$-mediated transcription by $\mathrm{ER} \alpha$-mix-siRNA-loaded NCs

The efficiency of siRNA-loaded NCs to alter ER $\alpha$-mediated transcription was measured. MELN cells were exposed to siRNAs trapped in nanocapsules in the presence or absence of $E_{2}$, and luciferase activity was measured after $48 \mathrm{~h}$, as described earlier (Figs. 2 and 4). $\mathrm{E}_{2}$-induced luciferase activity was reduced by $50 \%$ only in cells exposed to ER $\alpha$-mix-siRNAs NC (Fig. 4). This decrease was the highest inhibitory activity obtainable with the ER $\alpha$ mix-siRNA NC. However, a slight decrease in basal transcription was observed in cells exposed to empty $\mathrm{NC}$ or Scr-siRNA; this is probably due to weak cytotoxicity of the PCL/MA copolymer and/or to the transfection process.

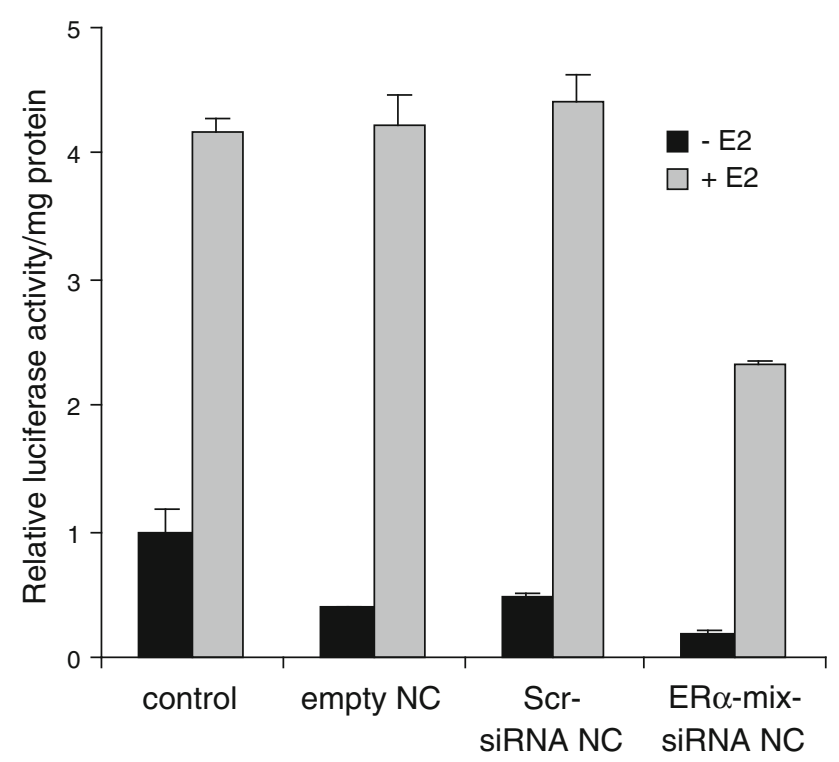

Fig. 4 Effect of ER $\alpha$-mix-siRNA-loaded nanocapsules on ER $\alpha$ mediated transcription; MELN cells were exposed or not to $50 \mathrm{nM}$, PEG-PCL/MA NC either empty or loaded with scramble siRNA or ER $\alpha$-mix-siRNA. After $32 \mathrm{~h}$, MELN cells were stimulated with $0.1 \mathrm{nM} \mathrm{E}_{2}$ for $16 \mathrm{~h}$. Cellular extracts were prepared and luciferase activity was measured. Results are expressed as the mean \pm SD of three independent experiments
Uptake of siRNA-loaded NCs by tumour cells in vivo

In order to study the capacity of PEG-PCL/MA NCs to deliver siRNA into tumour cells, we incorporated 5'-6FAM-siRNA at the same concentration as ER $\alpha$-mix-siRNA in PEG-PCL/MA NCs and injected them intravenously into mice bearing MCF-7 xenograft tumours. Mice were killed at different time intervals and tumours were removed, sliced and analysed by confocal laser fluorescence microscopy (Fig. 5). We observed substantial levels of fluorescence in tumour sections accumulating over time in the cytoplasm of tumour cells already at $6 \mathrm{~h}$ (white arrow); no fluorescence was observed in the untreated control tumours or in tumours from mice injected with equal amounts of free 5'-6-FAM-siRNA, whatever the time at which images were taken. After $24 \mathrm{~h}$, diffuse fluorescent siRNA signal had accumulated outside the cells (red arrow), with some signal remaining strongly associated with the cytoplasm of tumour cells. This could reflect an enhanced concentration of entrapped siRNAs as well as of released siRNAs from internalised NCs at the tumour level brought by the long circulation capacity of "stealth" NC through the important vasculature network. Alternatively, this could also be due to variability in tumours. Together with previous data showing uptake of ${ }^{33} \mathrm{P}$-ER $\alpha$-mix-siRNAs in MCF-7 cells [18], these data suggest that encapsulation in aqueous-core NCs protects siRNAs and promotes their internalisation by tumour cells both in vitro and in vivo. Additionally, pegylated NC displays a prolonged circulation in the bloodstream, remaining stable for at least $24 \mathrm{~h}$, with fluorescent siRNAs still observed in the cell cytoplasm.

Encapsulated ER $\alpha$-siRNAs act synergistically with RU-NS to inhibit ER $\alpha$ expression and vasculature in breast cancer tumours

Preliminary experiments showed that trapped siRNAs targeting $\mathrm{ER} \alpha$, but not Scr-siRNAs, injected intravenously into mice bearing MCF-7 cell tumours at $330 \mu \mathrm{g} / \mathrm{kg} / \mathrm{week}$, induced a decrease in ER $\alpha$ levels and a slight but significant decrease in the proliferation rate in tumour cells [18]. Since ER $\alpha$-siRNA inhibitory activity was able to potentiate AE-mediated effects in cells, we investigated these effects in vivo. Since RU trapped in NS markedly reduces tumour growth in MCF-7 cell xenografts after i.v. injection of $4.3 \mathrm{mg} \mathrm{RU} / \mathrm{kg} /$ week [17], we then injected RU encapsulated in PEG-PLGA NS at very low concentrations. In pilot experiments, not shown here, we found that RU at concentrations as low as $80 \mu \mathrm{g} / \mathrm{kg} /$ week was not able to affect, even slightly, the tumour growth in MCF-7 cells xenografts. We then decided to use a tenfold lower amount of $\mathrm{AE}$ trapped in nanocarrier (in fact $8.6 \mu \mathrm{g} / \mathrm{kg} / \mathrm{week}$ ). At 
Fig. 5 siRNA-loaded NC uptake by tumour cells $5^{\prime}$-6FAM-siRNA, free or loaded in NC (165 $\mu \mathrm{g}$ siRNA/kg), were i.v. injected into mice bearing xenografts of breast cancer MCF-7 cells. Mice were killed at different times and tumour cryo-sections were prepared. Slices were analysed by confocal microscopy (excitation at $488 \mathrm{~nm}$, emission collected at $505-550 \mathrm{~nm})$ at $\times 63$ magnification. Nomarski image shows living cells in good conditions confirming that MCF-7 cells viability was not affected by the treatments. After siRNA-loaded NC, white arrow indicates cytoplasmic localisation at $6 \mathrm{~h}$ and at $24 \mathrm{~h}$ and red arrow indicates extracellular localisation; both areas are shown at $\times 250$ magnification in corresponding inserts

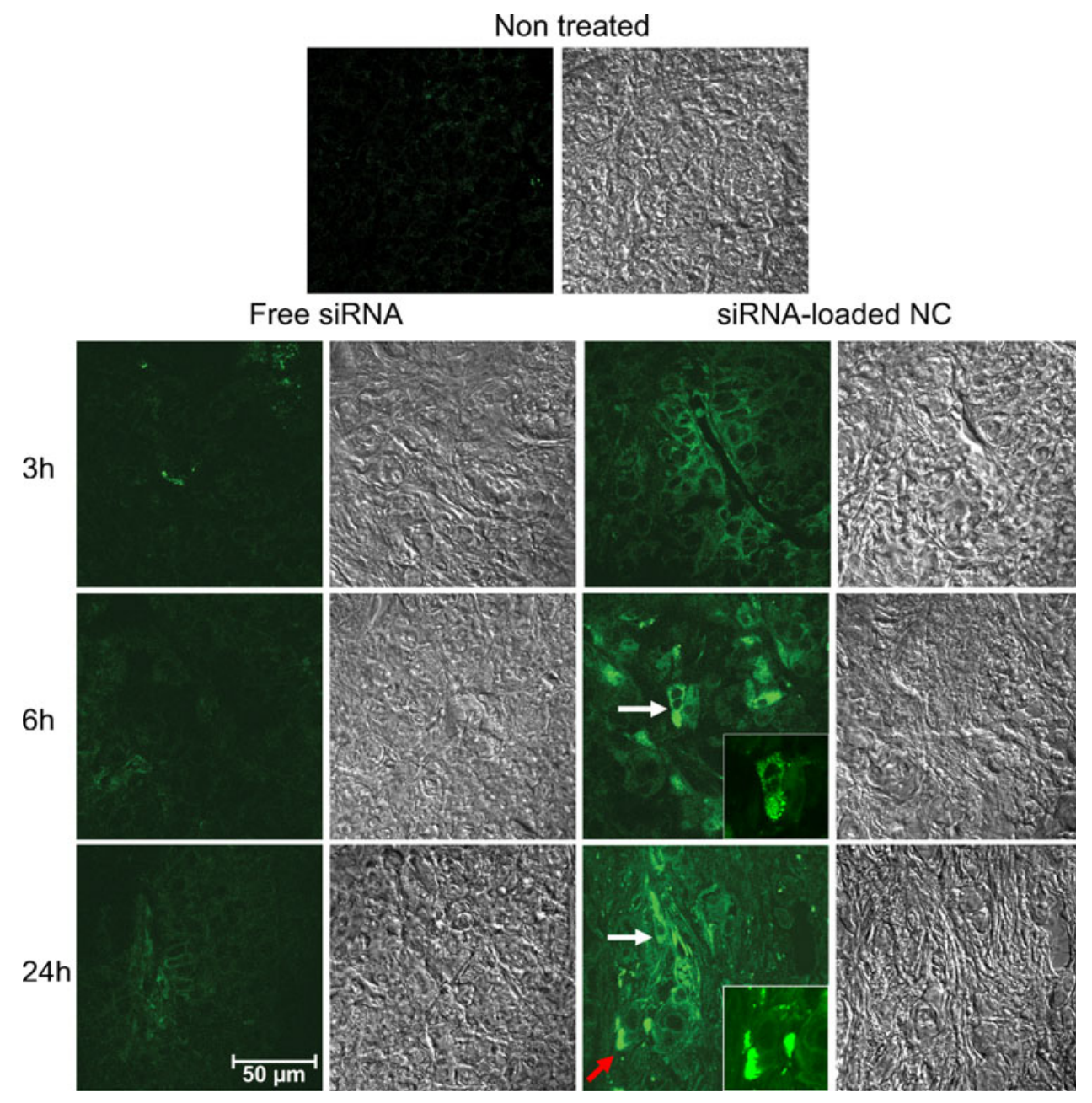

such concentrations, neither free RU [8, 28] nor encapsulated RU (our unpublished observations) had an effect on MCF-7 tumour growth.

The effects of the combined treatments were estimated by measuring with callipers the tumour evolution volumes and by studying the levels of various targets of $E_{2}$ by immunohistochemistry. Unfortunately, tumour measurement did not reveal significant differences (not shown) between the tumour volumes in the group of mice treated with ER $\alpha$-mix-siRNA NCs and the group of mice treated with the coadministration of the two treatments. This must be ascribed to imprecision in the measurements. However, even with RU-NS at RU concentration as low as $8.6 \mu \mathrm{g} / \mathrm{kg} /$ week, the number of tumour cells and ER $\alpha$ labelling after treatment over 5 weeks was lower than in tumours from mice injected with Scr-siRNA-loaded NC (Fig. 6a). Proliferating cells were mostly found at the tumour periphery, with necrotic tissue concentrated in the centre of the tumours. Analysis performed with the PIXCIT automatised software demonstrated that the Ki67 proliferative index was also decreased significantly in these tumours, as well as in tumours from mice treated with ER $\alpha$-mix-siRNA trapped in NC (Fig. 6b).

Notably, the down regulation of $\mathrm{ER} \alpha$ and the decrease in Ki67 labelling were more marked in tumours treated with both types of nanoparticles than in tumours receiving RU-loaded NS or trapped siRNAs alone. This suggests an additive anti-tumour effect of both treatments (Fig, 6a, b).

Effect of the inhibition of ER $\alpha$ protein expression on the vascularisation in solid tumours

It has been largely documented that $\mathrm{ER} \alpha$ regulates vascular endothelial growth factor (VEGF) expression both in tumour and in endothelial cells leading to inhibit $\mathrm{E}_{2}$-induced neo-angiogenesis [29-31]. In MCF-7 cells, tumours exposed to ER $\alpha$-mix-siRNA NCs and to RU-NS, the immunostaining demonstrated a weaker immunolabelling of the vascularisation marker CD34 (Fig. 6a). Noteworthy, the number and shape of tumour capillaries became more normalised after both treatments consistent 


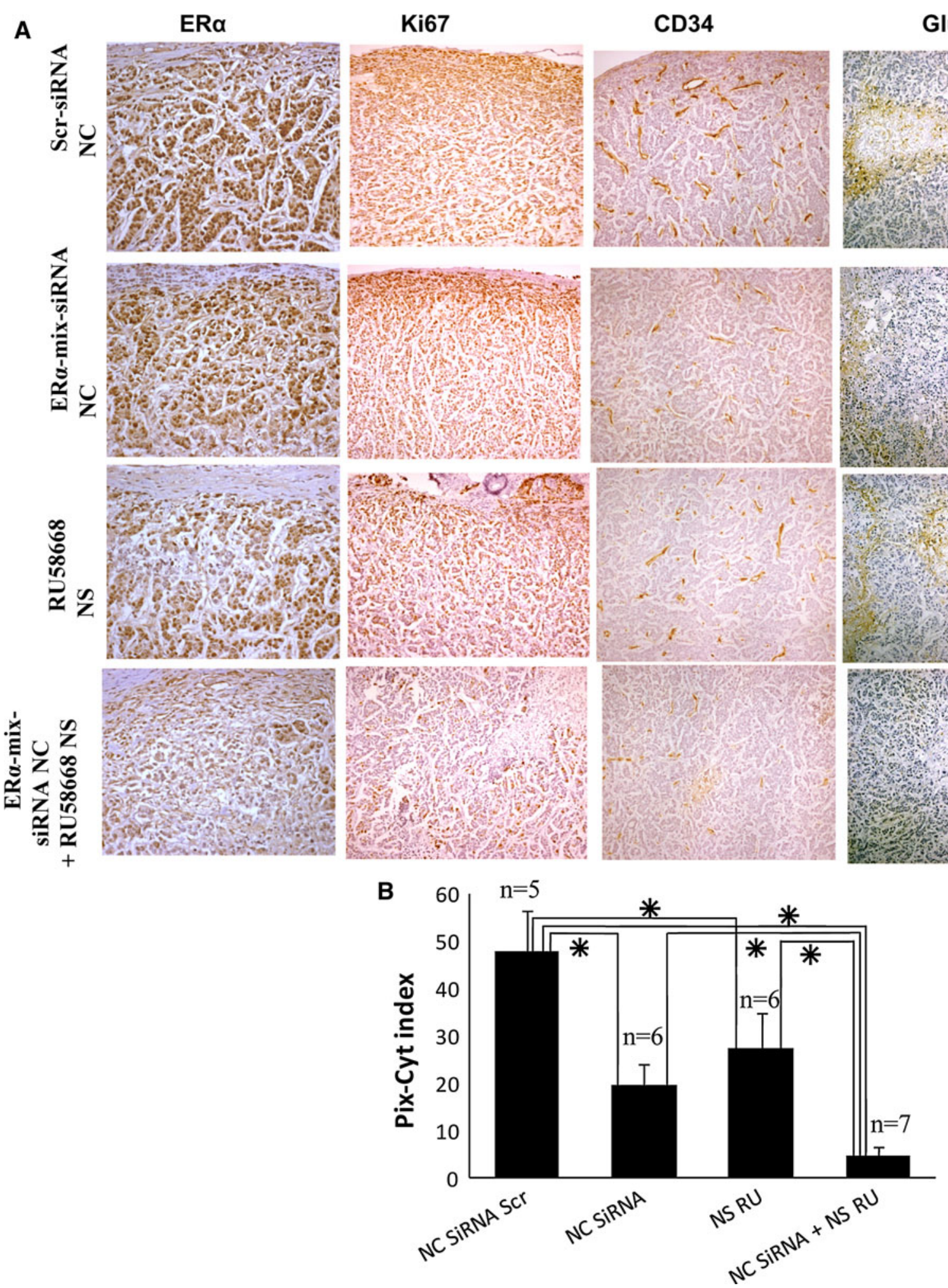

Fig. 6 Examination of paraffin-embedded sections from MCF-7 subcutaneous tumours a Mice bearing MCF-7 xenografts received scramble siRNA- or ER $\alpha$-mix-siRNA-loaded NC twice a week $(330 \mu \mathrm{g} / \mathrm{kg} /$ week), with or without treatment with RU-loaded NS $(8.5 \mu \mathrm{g} / \mathrm{kg} /$ week). After 5 weeks, mice were killed and tumours were removed fixed as described in "Material and methods" and treated for analysing $\mathrm{ER} \alpha, \mathrm{Ki} 67, \mathrm{CD} 34$ and Glut-1 protein content by immunohistochemistry. Sections were observed under a microscope at $\times 200$ original magnifications for $\mathrm{ER} \alpha$ and $\mathrm{Ki} 67$ and $\times 100$ for CD34 and Glut-1. B. Quantification of anti-Ki67 antibody-stained tumour sections using automatised PIXCYT software. Results are expressed as mean $\pm \mathrm{SD} \quad(n=$ number of tumours; five fields measured per tumour). Significant differences are indicated by the asterisk; results are considered statistically different for $P \leq 0.05$ 
A

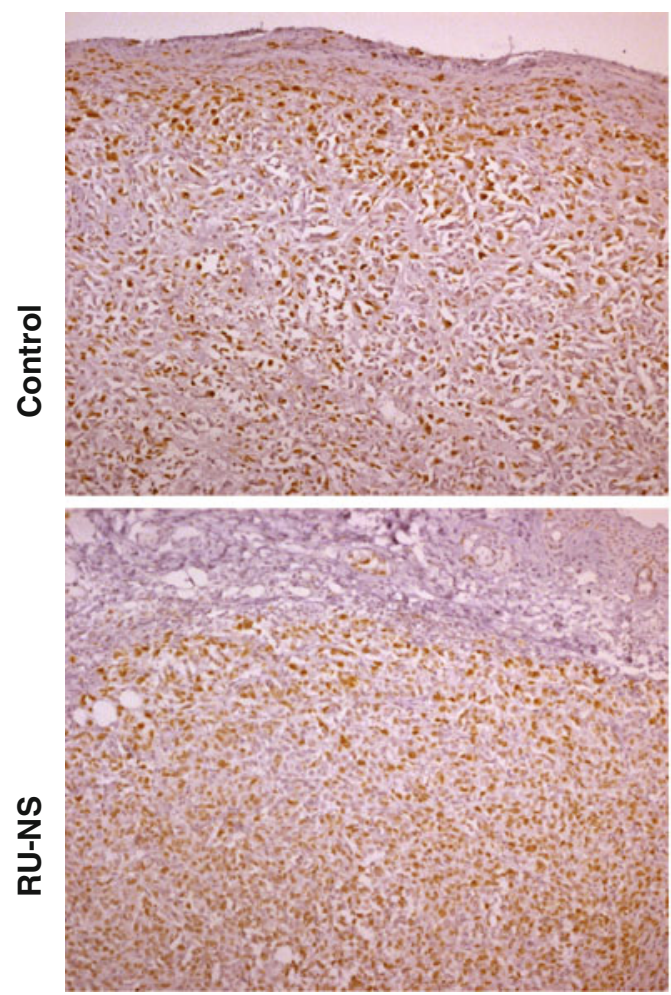

CD34
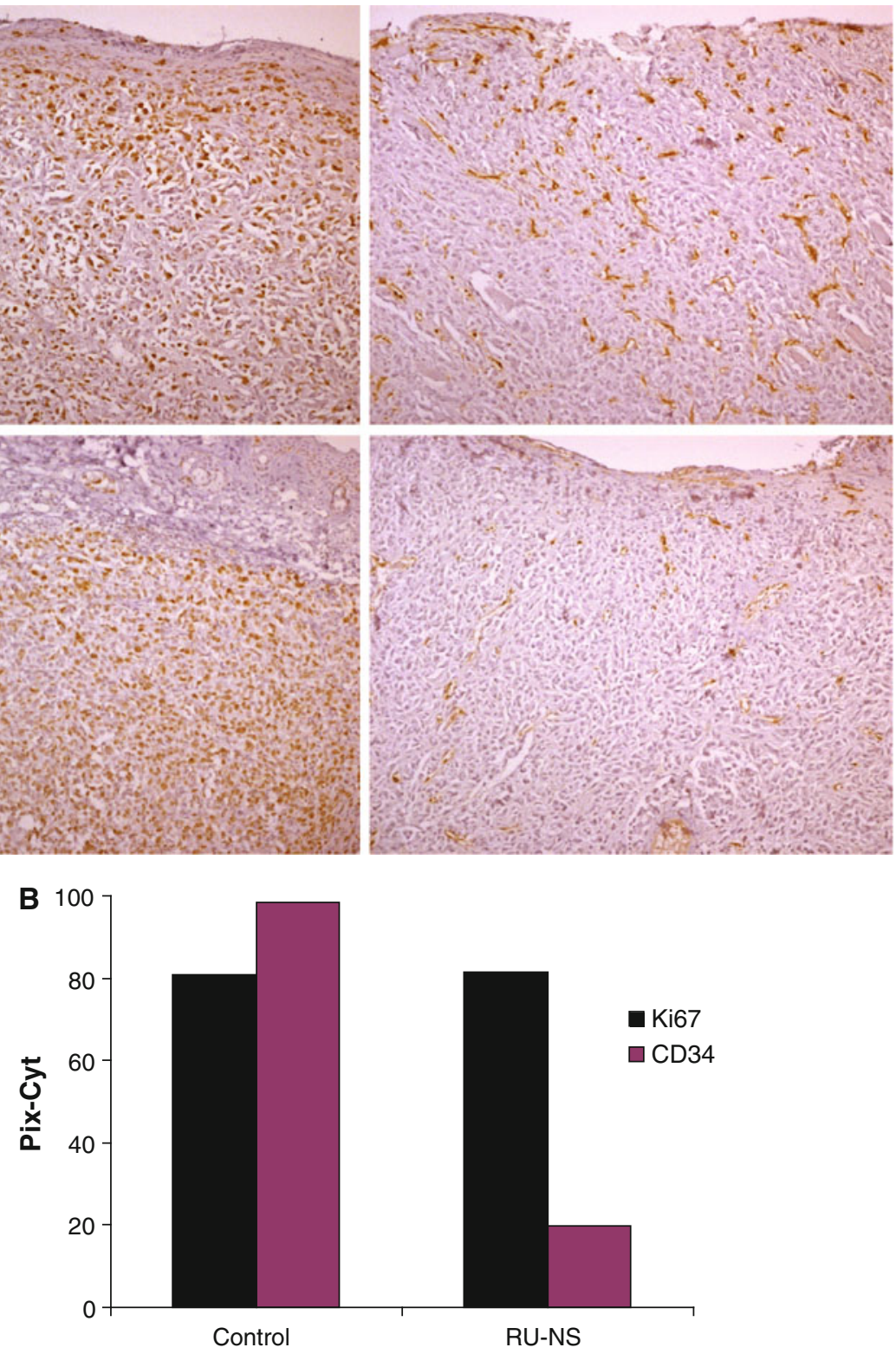

Fig. 7 Anti-vascular RU-stealth nanocarriers in MDA-MB-231 tumours. a Mice bearing ER-negative MDA-MB-231 cells tumours were treated or not with PEG-PLGA NS containing RU at $4.3 \mathrm{mg} / \mathrm{kg} /$ week. After 5 week treatment, tumours were analysed as in Fig. 6 for KI67 and CD34 labelling. b Histogram depicting the PIXCYT

with the regulation of tumour vessels by ER $\alpha$ signalling [32]. Quantification with PIXCYT software confirmed these results (not shown). Moreover, the use of the bitherapy indicated a synergistic decrease in CD34, in agreement with an enhanced anti-angiogenic activity.

Importantly, it has to be largely observed that many solid tumours, which need to be richly vascularised to proliferate and resist apoptosis, contain several necrotic areas and a number of destructurated angiogenic vessels. quantification of panel A. Five different fields from three independent tumours were quantified. A significant strong decrease in CD34 labelling was observed in tumours from mice treated with the RUloaded nanospheres $P \leq 0.0005$

Cells in hypoxia surround the necrotic areas and secrete the hypoxia-inducible factor- 1 which itself regulates the glucose transporter-1 protein (GLUT-1), an intrinsic marker of hypoxia [33]. We then analysed Glut-1 by immunohistological chemistry and found that if RU-NS had a weak but significant inhibitory effect of Glut-1, the effect of ER $\alpha$ mix-siRNA NC treatment was more pronounced and the bitherapy strongly indicated an almost total suppression of Glut-1 (Fig. 6a). 
Following the observation that the pure AE RU strongly affects the tumour vasculature in xenografts, we wondered if such an effect could occur in a xenograft model of ERnegative human breast cancer cells. As shown in Fig. 7, when mice bearing MDA-MB-231 tumours were treated with RU-NS at $4.3 \mathrm{mg} / \mathrm{kg} /$ week for 5 weeks, as expected, a significant decrease in CD34 labelling was seen. PIXCIT software analysis confirmed the significant decrease in the number of vessel density (Fig. 7b). However, no variation in the Ki67 labelling was observed, in good correlation with the absence of decrease in the tumour growth (not shown). This observation strongly indicates that $\mathrm{AE}$ delivery at high concentration in the environment of solid tumours affects angiogenesis.

\section{Discussion}

RNA interference (RNAi) is triggered by small doublestranded RNA (siRNA) and has sought to become a promising new therapeutic approach. RNAi-based strategies involve post-transcriptional gene silencing, resulting from the degradation of an mRNA target. Given their large molecular weight (approximately $15 \mathrm{kDa}$, corresponding to 19-23 nucleotides) and their polyanionic nature, few siRNAs cross biological barriers. Moreover, unmodified siRNAs are unstable in serum and blood, where they are rapidly degraded by nucleases; consequently, they have a short half-life in vivo. Thus, the main obstacle to achieving in vivo gene silencing using RNAi technology is the need for delivery systems to protect siRNA and facilitate its access and cellular uptake at target sites. Indeed, various strategies for in vivo siRNA delivery by systemic injection have been studied: lipoplexes, liposomes, polymers or chemically modified siRNA [34-36]. Numerous studies have investigated the use of in vivo siRNA directed against various targets, i.e. vascular endothelial growth factor (VEGF), bcl-2, Raf-1 or Erb-B2 (for review [37]).

In a previous report [18], we described, for the first time, the synthesis and the physico-chemical properties of a new type of pegylated nanocapsule incorporating a mixture of two specific siRNAs targeting $\mathrm{ER} \alpha$ ( $\operatorname{siRNA}-\mathrm{ER} \alpha$-mix). The formulation incorporated up to $0.5 \mu \mathrm{g}$ siRNA/mL and injected at the dose of $330 \mu \mathrm{g} / \mathrm{kg} /$ week, the highest dose injected so far, it was able to reduce by $50 \%$ the growth of the MCF-7, $\mathrm{E}_{2}$-dependent tumours. In order to augment the anti-tumour efficiency of the siRNA-ER $\alpha$-nanocarrier, it is quite possible that increasing amounts of administered siRNA would be necessary. This would only be performed by increasing the administration frequency of the i.v. injections since it was not possible to obtain a higher encapsulation rate. Nevertheless, this amount is in the range of concentrations of siRNA targeting Raf-1 [38],
VEGF [39-41] or the growth factor receptor Erb-B 2 [34, 35] used in other studies to target other mRNAs in nude mice bearing xenografts.

In vitro, the coadministration of AE with siRNA-ER $\alpha$ mix-NC revealed a synergistic effect (Fig. 3), although surprisingly more pronounced with RU than OHT. This apparent discrepancy could be attributed to different behaviour of AE-ER complexes. RU-ER $\alpha$ complexes, as other pure AE-ER complexes and contrary to OHT-ER $\alpha$ species are well known to be rapidly delocalised and then degraded through the proteasome pathway [12, 42]. Remaining OHT-ER could then be phosphorylated and the phosphorylated ER could activate certain genes encoding factors upregulating cell rate proliferation. As an example, exposure of MCF-7 cells transfected or not with $\operatorname{ER} \beta$ to either estradiol or OHT induced the expression of the "stromal-derived factor-1" (SDF-1) which in turn activates its membrane CXCR4 receptor leading to phosphorylate ER through the p42-44 MAPKinase pathway and activation of SDF-1 [43, 44]. Thus, a complete autocrine loop between CXCR4/SDF-1 and ERs signalling dictates ERdependent gene expression and growth of breast cancer cells. It is also possible that different signalling pathways emanating from the blockade [45] of the membrane ER by AE such as RU and OHT may affect the cell growth proliferation.

Our data show here that $\mathrm{E}_{2}$-induced transcription was not fully suppressed when cells were exposed to NC containing siRNA-ER $\alpha$-mix in MELN cells. This may reflect a lower efficiency of the trapped siRNA than that of the transfected siRNAs by the conventional transfection system, likely associated with the time-dependent endocytosis opposed to rapidly induced effects, respectively. As a consequence, siRNA released from NC may thus exert a smaller effect on ER $\alpha$ than transfection with siRNA, for the same duration. Under each condition, the same number of cells would not be equally transfected and remaining ER $\alpha$ could still be susceptible to activation by $E_{2}$. It is likely that siRNA-ER $\alpha$-mix are more efficient over a short period of time following transfection than siRNA-ER $\alpha$-mix-NC, which are themselves more efficient than free siRNA-ER $\alpha$ mix, when they are exposed to cells. This is consistent with the long-lasting decrease in ER $\alpha$ level following exposure of MCF-7 cells to NC. These inhibitory effects well correlate with a long time decrease in tumour $\mathrm{ER} \alpha$ protein (Fig. 6). However, both free and encapsulated siRNA-ER $\alpha$ mix potentiates the RU-induced decrease in $E_{2}$-induced transcription.

Many different parameters play an important role in the efficiency of the nanosystems used, particularly the administration route and the species from which the tumour is derived. Several of the preclinical assays based on the use of various nanocarriers that revealed anti-tumour 
efficiency used intratumour injection. This type of administration does not need pegylation of the nanoparticles; unfortunately, the pressure within the tumour in our MCF-7 xenograft model was too high to allow injected material to remain inside the tumour, and even low volumes lead to immediate leakage. Others have obtained satisfactory results following intraperitoneal injection of siRNA-loaded nanocarriers with amounts of siRNA at 120, 600 and $700 \mu \mathrm{g} / \mathrm{kg} /$ week [34, 38, 46], respectively. However, all these studies suggest that tumour-targeted liposomes and/or nanoparticles would improve efficiency of the anti-cancer agent $[39,47]$.

In another work, we showed that a nanocarrier transporting the pure AE RU was able to block the growth of MCF-7 cells tumours [17]. We chose to give very small concentrations of entrapped RU to these MCF-7 xenografts. At this low amount, neither free $[8,28]$ nor encapsulated RU (our unpublished observations) had an effect on the growth of the tumours. Nevertheless, as depicted in Fig. 6a, a decrease in ER $\alpha$ levels after 5 weeks of treatment with RU-NS was noticed. This decrease was potentiated by ER $\alpha$-mix-siRNA from NCs. At the same time, a decrease in the number of proliferating cells occurred, as revealed by the decreased number of Ki67labelled tumour cells in parallel to a decrease in CD34 labelling, indicating normalisation of the tumour vascular network. The decrease in ER $\alpha$ expression may lead to a decrease in $E_{2}$-triggered mitogenic activity. In fact, it has been shown that $E_{2}$ induces the activation of both the transcription factor hypoxia-inducible factor-1 (HIF-1) and the vascular endothelium growth factor (VEGF) in breast cancer cells [48] as well as in normal endothelial [31] and endometrial cells [49]. The decrease in levels of the Glut-1 may be associated with a decreased level of hypoxia in the treated tumours, resulting from a decreased tumour growth rate [50]. Indeed, VEGF-targeted therapy also induces a normalisation of the tumour vasculature, theoretically leading to a more uniform blood flow and thus leading to increased chemotherapeutic drug delivery [51]. Importantly, it should be noted that siRNA-ER $\alpha$ released from nanocapsules, even at the low dose injected, affect the tumour vasculature. Several reports have indicated that both $\mathrm{ER} \alpha$ and $\mathrm{ER} \beta$ are present in endothelial cells [52] and that oestradiol induces synthesis and excretion of VEGF and soluble VEGF receptor-1, an effect inhibited by AE such as OHT, raloxifen and ICI 182,780 [53]. Moreover, there are a variety of ER splice variants and a truncated $\mathrm{ER} \alpha$ (ER46) localised at the membrane mediates the rapid effects of oestradiol which are abrogated by AE [54]. Other data have demonstrated that $\mathrm{AE}$ acts as strong anti-angiogenic compounds on the chorioallantoic membrane [55]. Altogether, the data from the present paper indicate an effect on the $E_{2}$-induced synthesis of VEGF through diminution of ER $\alpha$ in epithelial tumour cells, which could act via a paracrine and an autocrine action on both epithelial and endothelial cells by decreasing VEGF as already observed in another type of solid tumour [56]. In addition, siRNA-ER $\alpha$ released from nanocapsules may directly suppress VEGF production by endothelial cells. Given that siRNA-ER $\alpha$-mix-NC and RU-NS-induced normalisation of the vasculature, we would expect their use in combination with another chemotherapy agent to potentiate their antitumour activity $[57,58]$. Such a perspective is strengthen by recent works demonstrated that anti-angiogenic targeting liposomes enhance the therapeutic efficacy of liposomal doxorubicin [59].

Our data support the use of ER $\alpha$-siRNA incorporated in long-circulating nanocarriers as an efficient tool for inhibiting the growth of oestrogen-dependent breast cancer tumour growth. Selective uptake by tumours could be further enhanced by coupling tumour recognition molecules to the ends of PEG chains. Indeed, and despite some contradictory findings [60], it has been mostly shown that specific tumour targeting increases the delivery of an encapsulated anti-cancer agent by enhancing endocytosis of targeted nanosystems [61]. The coupling of herceptin [62]—or any other antibody specific for a surface receptor considered a potential therapeutic target—could be of particular interest for use in a "double shotgun" approach to delivering a specific anti-cancer drug.

Acknowledgments $\mathrm{CB}$ had a fellowship from the Ministere de l'Enseignement, de la Recherche et de la Technologie and from the Association pour la Recherche sur le Cancer. We thank M. Pons and P. Ballaguer for the gift of MELN cells and the Service commun d'expérimentation animale from the IFR 141 (Châtenay-Malabry).

Funding This work was supported by the Centre National de la Recherche Scientifique, the University of Paris-Sud and by the Ligue Nationale contre le Cancer (Comité des Hauts de Seine). Funding to pay the Open Access publication charges for this article was provided by the CNRS.

Conflict of interest statement Nothing to declare.

\section{References}

1. Fisher B et al (1994) Endometrial cancer in tamoxifen-treated breast cancer patients: findings from the national surgical adjuvant breast and bowel project (NSABP) B-14. J Natl Cancer Inst 86(7):527-537

2. Assikis VJ, Jordan VC (1995) Gynecologic effects of tamoxifen and the association with endometrial carcinoma. Int $\mathrm{J}$ Gynaecol Obstet 49(3):241-257

3. Mangelsdorf DJ et al (1995) The nuclear receptor superfamily: the second decade. Cell 83(6):835-839

4. Jordan VC (2003) Antiestrogens and selective estrogen receptor modulators as multifunctional medicines. 2. Clinical considerations and new agents. J Med Chem 46(7):1081-1111

5. Heldring $N$ et al (2007) Estrogen receptors: how do they signal and what are their targets. Physiol Rev 87(3):905-931 
6. Early Breast Cancer Trialists' collaborative group. (2005) Effects of chemotherapy and hormonal therapy for early breast cancer on recurrence and 15-year survival: an overview of the randomised trials. Lancet 365(9472):1687-1717

7. Wakeling AE, Bowler J (1992) ICI 182, 780, a new antioestrogen with clinical potential. J Steroid Biochem Mol Biol 43(1-3): 173-177

8. Van de Velde P et al (1994) RU 58, 668, a new pure antiestrogen inducing a regression of human mammary carcinoma implanted in nude mice. J Steroid Biochem Mol Biol 48(2-3):187-196

9. Alarid ET, Bakopoulos N, Solodin N (1993) Proteasome-mediated proteolysis of estrogen receptor: a novel component in autologous down-regulation. Mol Endocrinol 13(9):1522-1534

10. El Khissiin A, Leclercq G (1999) Implication of proteasome in estrogen receptor degradation. FEBS Lett 448(1):160-166

11. Wijayaratne AL, McDonnell DP (2001) The human estrogen receptor-alpha is a ubiquitinated protein whose stability is affected differentially by agonists, antagonists, and selective estrogen receptor modulators. J Biol Chem 276(38):35684-35692

12. Marsaud V et al (2003) Various phosphorylation pathways, depending on agonist and antagonist binding to endogenous estrogen receptor alpha (ERalpha), differentially affect ERalpha extractability, proteasome-mediated stability, and transcriptional activity in human breast cancer cells. Mol Endocrinol 17(10): 2013-2027

13. Montanaro D et al (2005) Antiestrogens upregulate estrogen receptor beta expression and inhibit adrenocortical H295R cell proliferation. J Mol Endocrinol 35(2):245-256

14. Gougelet A et al (2007) Oestrogen receptors pathways to oestrogen responsive elements: the transactivation function-1 acts as the keystone of oestrogen receptor (ER)beta-mediated transcriptional repression of ERalpha. J Steroid Biochem Mol Biol 104(3-5): $110-122$

15. Holst $\mathrm{F}$ et al (2007) Estrogen receptor alpha (ESR1) gene amplification is frequent in breast cancer. Nat Genet 39(5):655-660

16. Renoir JM et al (2006) Improved anti-tumoral capacity of mixed and pure anti-oestrogens in breast cancer cell xenografts after their administration by entrapment in colloidal nanosystems. $\mathbf{J}$ Steroid Biochem Mol Biol 102(1-5):114-127

17. Ameller $\mathrm{T}$ et al (2003) In vitro and in vivo biologic evaluation of long-circulating biodegradable drug carriers loaded with the pure antiestrogen RU 58668. Int J Cancer 106(3):446-454

18. Bouclier C et al (2008) Physicochemical characteristics and preliminary in vivo biological evaluation of nanocapsules loaded with siRNA targeting estrogen receptor alpha. Biomacromolecules 9(10):2881-2890

19. Gabizon A, Martin F (1997) Polyethylene glycol-coated (pegylated) liposomal doxorubicin. Rationale for use in solid tumours. Drugs 54(Suppl 4):15-21

20. Allen TM et al (1991) Liposomes containing synthetic lipid derivatives of poly(ethylene glycol) show prolonged circulation half-lives in vivo. Biochim Biophys Acta 1066(1):29-36

21. Storm $G$ et al (1995) Surface modification of nanoparticles to oppose uptake by the mononuclear phagocyte system. Adv Drug Deliv Rev 17(1):31-48

22. Gagne D et al (1994) Stable luciferase transfected cells for studying steroid receptor biological activity. J Biolumin Chemilumin 9(3):201-209

23. Ameller T et al (2003) Polyester-poly(ethylene glycol) nanoparticles loaded with the pure antiestrogen RU 58668: physicochemical and opsonization properties. Pharm Res 20(7):1063-1070

24. Elie $\mathrm{N}$ et al (2003) A simple way of quantifying immunostained cell nuclei on the whole histologic section. Cytometry A 56(1): $37-45$

25. Wittmann BM, Sherk A, McDonnell DP (2007) Definition of functionally important mechanistic differences among selective estrogen receptor down-regulators. Cancer Res 67(19):9549_ 9560

26. Nardulli AM et al (1988) Regulation of progesterone receptor messenger ribonucleic acid and protein levels in MCF-7 cells by estradiol: analysis of estrogen's effect on progesterone receptor synthesis and degradation. Endocrinology 122(3):935-944

27. Petz LN, Nardulli AM (2000) Sp1 binding sites and an estrogen response element half-site are involved in regulation of the human progesterone receptor A promoter. Mol Endocrinol 14(7):972-985

28. Van de Velde P et al (1996) RU 58668: further in vitro and in vivo pharmacological data related to its antitumoral activity. J Steroid Biochem Mol Biol 59(5-6):449-457

29. Buteau-Lozano $\mathrm{H}$ et al (2002) Transcriptional regulation of vascular endothelial growth factor by estradiol and tamoxifen in breast cancer cells: a complex interplay between estrogen receptors alpha and beta. Cancer Res 62(17):4977-4984

30. Applanat MP et al (2008) Vascular endothelial growth factor is a target gene for estrogen receptor and contributes to breast cancer progression. Adv Exp Med Biol 617:437-444

31. Gavin KM, et al. (2009) Vascular Endothelial estrogen receptor \{alpha $\}$ is modulated by estrogen status and related to endothelial function and eNOS in healthy women. J Clin Endocrinol Metab 94(9):3513-3520

32. Fukumura D, Jain RK (2007) Tumor microvasculature and microenvironment: targets for anti-angiogenesis and normalization. Microvasc Res 74(2-3):72-84

33. Rankin EB, Giaccia AJ (2008) The role of hypoxia-inducible factors in tumorigenesis. Cell Death Differ 15(4):678-685

34. Urban-Klein B et al (2005) RNAi-mediated gene-targeting through systemic application of polyethylenimine (PEI)-complexed siRNA in vivo. Gene Ther 12(5):461-466

35. Pirollo KF et al (2007) Materializing the potential of small interfering RNA via a tumor-targeting nanodelivery system. Cancer Res 67(7):2938-2943

36. Soutschek J et al (2004) Therapeutic silencing of an endogenous gene by systemic administration of modified siRNAs. Nature 432(7014): $173-178$

37. Aigner A (2007) Applications of RNA interference: current state and prospects for siRNA-based strategies in vivo. Appl Microbiol Biotechnol 76(1):9-21

38. Leng Q, Mixson AJ (2005) Small interfering RNA targeting Raf1 inhibits tumor growth in vitro and in vivo. Cancer Gene Ther 12(8):682-690

39. Schiffelers RM et al (2004) Cancer siRNA therapy by tumor selective delivery with ligand-targeted sterically stabilized nanoparticle. Nucleic Acids Res 32(19):e149

40. Kim SH et al (2008) Local and systemic delivery of VEGF siRNA using polyelectrolyte complex micelles for effective treatment of cancer. J Control Release 129(2):107-116

41. He XW et al (2008) Calcium carbonate nanoparticle delivering vascular endothelial growth factor-C siRNA effectively inhibits lymphangiogenesis and growth of gastric cancer in vivo. Cancer Gene Ther 15(3):193-202

42. Stenoien DL et al (2001) FRAP reveals that mobility of oestrogen receptor-alpha is ligand- and proteasome-dependent. Nat Cell Biol 3(1):15-23

43. Hall JM, Korach KS (2003) Stromal cell-derived factor 1, a novel target of estrogen receptor action, mediates the mitogenic effects of estradiol in ovarian and breast cancer cells. Mol Endocrinol 17(5):792-803

44. Sauve K et al (2009) Positive feedback activation of estrogen receptors by the CXCL12-CXCR4 pathway. Cancer Res 69(14):5793-5800

45. Pedram A et al (2002) Integration of the non-genomic and genomic actions of estrogen. Membrane-initiated signaling by 
steroid to transcription and cell biology. J Biol Chem 277(52): 50768-50775

46. Landen $\mathrm{CN} \mathrm{Jr}$ et al (2005) Therapeutic EphA2 gene targeting in vivo using neutral liposomal small interfering RNA delivery. Cancer Res 65(15):6910-6918

47. Pirollo KF et al (2006) Tumor-targeting nanoimmunoliposome complex for short interfering RNA delivery. Hum Gene Ther 17(1):117-124

48. Li J et al (2006) Knockdown of hypoxia-inducible factor-1alpha in breast carcinoma MCF-7 cells results in reduced tumor growth and increased sensitivity to methotrexate. Biochem Biophys Res Commun 342(4):1341-1351

49. Kazi AA, Koos RD (2007) Estrogen-induced activation of hypoxia-inducible factor-1alpha, vascular endothelial growth factor expression, and edema in the uterus are mediated by the phosphatidylinositol 3-kinase/Akt pathway. Endocrinology 148(5):2363-2374

50. Hoskin PJ et al (2003) GLUT1 and CAIX as intrinsic markers of hypoxia in bladder cancer: relationship with vascularity and proliferation as predictors of outcome of ARCON. Br J Cancer 89(7):1290-1297

51. Dickson PV et al (2007) Bevacizumab-induced transient remodeling of the vasculature in neuroblastoma xenografts results in improved delivery and efficacy of systemically administered chemotherapy. Clin Cancer Res 13(13):3942-3950

52. Hyder SM (2006) Sex-steroid regulation of vascular endothelial growth factor in breast cancer. Endocr Relat Cancer 13(3): $667-687$
53. Garvin S, Dabrosin C (2003) Tamoxifen inhibits secretion of vascular endothelial growth factor in breast cancer in vivo. Cancer Res 63(24):8742-8748

54. Kim KH, Bender JR (2009) Membrane-initiated actions of estrogen on the endothelium. Mol Cell Endocrinol 308(1-2):3-8

55. Gagliardi A, Collins DC (1993) Inhibition of angiogenesis by antiestrogens. Cancer Res 53(3):533-535

56. Maillard S et al (2006) Improved antitumoral properties of pure antiestrogen RU 58668-loaded liposomes in multiple myeloma. J Steroid Biochem Mol Biol 100(1-3):67-78

57. Schlotter CM et al (2008) Molecular targeted therapies for breast cancer treatment. Breast Cancer Res 10(4):211

58. Smiley DA, Khalil RA (2009) Estrogenic compounds, estrogen receptors and vascular cell signaling in the aging blood vessels. Curr Med Chem 16(15):1863-1887

59. Chang DK et al (2009) Antiangiogenic targeting liposomes increase therapeutic efficacy for solid tumors. J Biol Chem 284(19):12905-12916

60. Pirollo KF, Chang EH (2008) Does a targeting ligand influence nanoparticle tumor localization or uptake? Trends Biotechnol 26(10):552-558

61. Kirpotin DB et al (2006) Antibody targeting of long-circulating lipidic nanoparticles does not increase tumor localization but does increase internalization in animal models. Cancer Res 66(13):6732-6740

62. Kirpotin D et al (1997) Sterically stabilized anti-HER2 immunoliposomes: design and targeting to human breast cancer cells in vitro. Biochemistry 36(1):66-75 